\title{
Computer Numerical Simulation of Sluice Structure on Deep Overburden Foundation
}

\author{
Xuan Wang \\ Hohai University \\ Nanjing, Jiangsu \\ 504114903@qq.com
}

Weiping $\mathrm{Hu}$

Water Conservancy Project Construction Bureau of

Jiangsu Province

Nanjing, Jiangsu

563355178@qq.com

\author{
Xuanmao Peng \\ Hohai University \\ Nanjing, Jiangsu \\ pengxuanmao@sina.com
}

\begin{abstract}
This paper adopts the space combination finite element method to calculate the whole displacement and stress of chamber structure and foundation, calculates the overall stability against sliding and anti-floating stability safety coefficient of the lock chamber structure via the rigid body limit equilibrium method, and simulates the excavation and backfill of the covering through the method of the nonlinear variable stiffness. The calculation model effectively considers the lock chamber structure, foundation interaction and the influence of lock chamber structure on both sides of the concrete dam.
\end{abstract}

Keywords-Deep Overbu rden Layer; Lock Structure; Strees; Srain; Numerical Analysis

\section{INTRODUCTION}

At present, the design specification for sluice[1] in China is mainly applied to various sluices under the conditions of low water head in the plain areas. In the sluice construction, when constructing the project sluice on the foundation with deep overburden sand layers in the mountain area, for the foundation condition is complicated and the water head is high, which make the structure size much larger than that of the common plain sluice. The stress status is very complicated and the design requirements cannot be satisfied according to the regular mechanical analysis method. There, it is very necessary to adopt the advanced numerical analys is method to perform the overall numerical analys is to the sluice structure on the deep overburden layer foundation. In this article, it combines with the project sluice of a hydroelectric power station's first control project to perform the calculation, analys is and research to the project sluice structure on the deep overburden sand layer foundation. The calculation model effectively takes the interactions between the pier, bottom plate and complicated foundation, There the obtained calculation result complies with the general rules.

This hydroelectric power station is a low-gate and high- water head water diversion power station mainly generating electricity, this station is installed with two 65 MW hydrogenerator groups in total with the total installed capacity of $130 \mathrm{MW}$. The normal storage level of the station is $1674.00 \mathrm{~m}$, with the corresponding reservoir capacity of 2.08 million $\mathrm{m} 3$, and the maximum sluice height of $27.0 \mathrm{~m}$. Except for the foundation of partial retaining dam sections on the left and right banks being placed on the weakly weathered bedrocks, the sluice chamber and other retaining dam sections are all placed on the alluvial gravel layers.

Set a sand sluice on the right side of the river bed close to the water intakes downstream, and lay three discharge sluices on the left side of the sand sluice to form the arrangement of "laterally water intakes, forward discharge and sediment".

The orifice size of the sand sluice is $3.0 \mathrm{~m} \times 5.0 \mathrm{~m}$ $(\mathrm{W} \times \mathrm{H})$, and the orifice size of the discharge sluice is $10.0 \mathrm{~m} \times 12.0 \mathrm{~m}(\mathrm{~W} \times \mathrm{H})$, the elevations of the bottom plates in the sluice chamber are all $1654.50 \mathrm{~m}$, and the total length of each sluice chamber is $42 \mathrm{~m}$.

\section{PRINCIPLE AND METHOD OF CALCULATION}

\section{A. Establishment and resolution of the governing equation}

As for the complicated foundation and backfill concrete structures, adopt the coordination units such as the space hexahedrons to perform the discretion, as for the sluice chamber structures, adopt the space noncoordination units better reflecting the bending performances to perform the discretion. Combine all categories of ele ments together, and for the sluice chamber structures, adopt the space non-coordination units better reflecting the bending. Combine all categories of units together and adopt the space combination FEM for calculation.

According to the balance conditions of the element nodes, combine the balance equation of each node on the structure together, the governing equation solving the node displacement with the FEM can be obtained as

$$
[K]\{\delta\}=\{R\} \text {. }
$$


In which, $\{\delta\}$ overall node displacement is the set of each element node displacement; $\{R\}$ is the overall node loading, which can be combined by each element node loading; $[K]$ is the overall stiffness matrix, which can be combined by each element stiffness matrix. The element stiffness matrix of the non-coordination element can be obtained through the cohesion method as follows:

$\left[K^{e}\right]=\left[K_{u u}^{e}\right]-\left[K_{u \bar{u}}^{e}\right]\left[K_{u \bar{u}}^{e}\right]^{-1}\left[K_{u u}^{e}\right]$

In which,

$$
\begin{aligned}
& {\left[K_{u u}^{e}\right]=\iiint_{v^{e}}[B]^{T}[D][B] d V} \\
& {\left[K_{\bar{u} u}^{e}\right]=\iiint_{v^{e}}[\bar{B}]^{T}[D][B] d V} \\
& {\left[K_{u \bar{u}}^{e}\right]=\iiint_{v^{e}}[B]^{T}[D][\bar{B}] d V} \\
& {\left[K_{\overline{u u}}^{e}\right]=\iint_{v^{e}}[\bar{B}]^{T}[D][\bar{B}] d V}
\end{aligned}
$$

After solving $\{\delta\}$, the displacement, strain and stress of each element arbitrary node can be solved. And finally arrange into various required results according to the project requirements.

\section{B. Simulation of Excavation and concrete backfill for the overburden layers}

As for the general overburden layers, the basic method of treatment is adopting the replacement method. For the excavation and backfill volumes are very huge so as the differences between the material qualities. It should take the influences of excavation and backfill processes to the structure stress especially the foundation stress into consideration. The simulation calculation of excavation and backfill is actually a non-liner calculation process for the variable rigidity ${ }^{[3]}$. During the calculation, solve the foundation stress field of the natural foundation under the dead weight conditions according to the natural foundation rigidity, then release the stress on the excavation surface, and then after displacing the excavation part into concrete, taking the dead weight of concrete to perform calculation according to the new rigidity, take the current foundation stress field as the initial stress field. The key points of this calculation process are change of the area rigidity and calculation of the excavation surface.

According to the force equaling to the reaction force, opposite directions principle and the balance conditions, it can be obtained:

$$
\begin{aligned}
& \sum_{e \in E_{\Omega_{1}}} \iiint_{\Omega_{e}}[C]^{e}[B]^{T}\left\{\sigma_{0}\right\}^{e} d \Omega=\{\Delta F\} \\
& +\sum_{e \in E_{\Omega_{1}}} \iiint_{\Omega_{e}}[C]^{e}[N]^{T}\{Y\}^{e} d \Omega
\end{aligned}
$$
as:

There the excavation loading $\{\Delta F\}$ can be expresses

$$
\begin{aligned}
& \{\Delta F\}=\sum_{e \in E_{\Omega_{1}}} \iiint_{\Omega_{e}}[C]^{e}[B]^{T}\left\{\sigma_{0}\right\}^{e} d \Omega \\
& -\sum_{e \in E_{\Omega_{1}}} \iiint_{\Omega_{e}}[C]^{e}[N]^{T}\{Y\}^{e} d \Omega
\end{aligned}
$$

In which, $\left\{\sigma_{0}\right\}^{e}$ is the stress of $e$ element before excavation, $[B]$ is the element strain matrix, $[C]^{e}$ is the element selection matrix whose elements composing of Oand $1,[N]$ is the shape function of $e$ element. $\{Y\}$ is the physical density matrix of $e$ element, when only the dead weight works along y direction, the element bulk is $\gamma$, then

$$
\{Y\}=\left\{\begin{array}{lll}
0 & -\gamma & 0
\end{array}\right\}
$$

After obtaining the equivalent node loading, perform the superposition to the results obtained before and after excavation with calculation, the results after excavation will be obtained.

\section{Overall stability calculation of the sluice chamber structure}

According to the obtained element stress on the bottom plate of the sluice chamber and the rock foundation contact surface, and by the rigidity limit equilibrium principle, calculate the overall anti-slide safety factor $\mathrm{K}$ of the sluice chamber with the anti-shearstrength formula as:

$$
K=\frac{\sum_{i=1}^{e}\left(\sigma_{n i} f^{\prime}+c^{\prime}\right) A_{i}}{\sum_{i=1}^{e} \tau_{s i} A_{i}}
$$

In which, $f^{\prime}, c^{\prime}$ - separately represent the friction factor and cohesion force of the bottom plate of sluice chamber and the rock foundation; $\sigma_{n i}$ and $\tau_{s i}$ separately represent the normal positive stress and shearing stress of $i$ contact surface paralleling to the vertical plane; $A_{i}$ is the normal plane area of $i$ element; ${ }^{e}-$ is the element sum on the bottom plate of sluice chamber and rock foundation contact surface.

\section{Overall anti-floating calculation of the sluice chamber structure}

According to the vertical element stress on the bottom plate of sluice chamber and rock foundation contact surface and also according to the limit balance principle to solve the overall anti-floating safety factor $K_{f}$ of the dam as:

$$
K_{f}=\frac{\sum_{i=1}^{e} \sigma_{z}^{\prime} A_{i}}{\sum_{i=1}^{e} \sigma_{z}^{\prime \prime} A_{i}}
$$


In this formula, $\sigma_{z}^{\prime}$ - is the vertical stress of the contact surface element caused under the loading function besides the uplift pressure; $\sigma_{z}^{\prime \prime}$ is the vertical stress of the contact surface element caused the only uplift pressure function; $A_{i}$ - is the normal plane area of $i$ element; $e_{-}$is the element sum on the bottom plate of sluice chamber and rock foundation contact surface.

\section{BASIC MATERIALS OF CALCULATION}

According to the relevant data, the physical and mechanical parameters of concrete and foundation materials take the values as follows:

TABLE I. OVERBURDEN LAYERS OFDAM FOUNDATION AND MECHANICAL PARAMETER TABLE

\begin{tabular}{|c|c|c|c|c|c|c|}
\hline NO. & material & $\begin{array}{l}\text { Volume } \\
/ \mathrm{t} \cdot \mathrm{m}^{-3}\end{array}$ & $\begin{array}{l}\text { Deformation } \\
\text { modulus } \\
/ \mathrm{MPa}\end{array}$ & $\begin{array}{c}\text { poisson' } \\
\text { s } \\
\text { Ratio }\end{array}$ & $\begin{array}{l}\text { Cohesive } \\
\text { force } \\
/ \mathrm{MPa}\end{array}$ & $\begin{array}{c}\text { Internal } \\
\text { friction } \\
\text { angle } \\
/\left(^{\circ}\right)\end{array}$ \\
\hline 1 & $\begin{array}{l}\text { Concret } \\
\text { e C10 }\end{array}$ & 2.45 & $1.0 \times 104$ & 0.167 & & \\
\hline 2 & $\begin{array}{l}\text { Concret } \\
\text { e C20 }\end{array}$ & 2.45 & $2.6 \times 104$ & 0.167 & & \\
\hline 3 & $\begin{array}{l}\text { Concret } \\
\text { e C25 }\end{array}$ & 2.45 & $2.85 \times 104$ & 0.167 & & \\
\hline 4 & Q4a1-1 & 2.18 & $10 \sim 20$ & 0.35 & 0 & $30 \sim 32$ \\
\hline 5 & Q4a1-2 & 2.18 & $20 \sim 30$ & 0.3 & 0 & $30 \sim 33$ \\
\hline 6 & Q4a1-3 & 2.18 & 30 40 & 0.3 & 0 & $32 \sim 35$ \\
\hline 7 & $\begin{array}{c}\text { Limesto } \\
\text { ne }\end{array}$ & 2.72 & $3 \sim 5 \times 103$ & 0.22 & $0.6 \sim 0.5$ & $38 \sim 31$ \\
\hline 8 & $\begin{array}{c}\text { Limesto } \\
\text { ne }\end{array}$ & 2.77 & $1 \sim 1.5 \times 103$ & 0.21 & $0.3 \sim 0.2$ & $27 \sim 22$ \\
\hline
\end{tabular}

IV. CALCULATING THE WORKING CONDITIONS AND LOADING COMBINATION

The main basic loading considered by the calculation can be divided as the following categories: (1) dead weight of the sluice chamber structure, (2) additional loading on the concrete structure of the sluice chamber, (3) water pressure (highest storage level $1674.00 \mathrm{~m}$, downstream water level $1649 \mathrm{~m}$ ), (4) uplift pressure, (5) thrust force of radial gate (thrust force of single trunnion of the discharge sluice is $12000 \mathrm{kN}$, horizontal angle is $16.23^{\circ}$, lateral thrust force is $1250 \mathrm{kN}$. thrust force of single trunnion of the sand sluice is $2500 \mathrm{kN}$, horizontal angle is $35.38^{\circ}$, lateral thrust force is $0 \mathrm{kN}$.) (6) earth pressure filling pressure on the sidewall), (7) equivalent side loading caused by the left and right reaction force of concrete dam, (8) side loading caused by the left and right backfill, (9) equivalent side loading caused by the upstream cladding structure, (10) equivalent side loading caused by the downstream apron structure, (11) equivalent loading caused by the downstream guide wall, (12) earthquake loading (take the earthquakes along and vertical to the river direction into consideration at the same time, and the PGA is $0.117 \mathrm{~g}$ ). Taking three categories of calculation working conditions, whose loading combination are as shown below:

Completion period: $(1)+(2)+(6) \sim(11)$

Storage period: $(1) \sim(11)$

Earthquake period: (1) (12)

\section{CALCULATION MODEL}

Take the whole sluice chamber structures of discharge sluice and sand sluice as the calculation object, and take the interactions between the overall pier, parapet, corbel, bottom plate structure and the foundation into consideration. Replace the functions of the neighboring sluice chamber left and right dam structures as well as the upstream cladding structure and downstream apron with the side loading. Take the sluice chamber concrete structure, backfilling concrete foundation and foundation within certain scope as an overall split FEM network. The scope of foundation is: $205 \mathrm{~m}$ in total along the left and right direction of the sluice chamber, in which, taking the left side to the dam (sluice) left $0+100 \mathrm{~m}$, taking the right side to the dam (sluice)right $0+105 \mathrm{~m} ; 117 \mathrm{~m}$ in total along the upstream and downstream direction, in which, taking the upstream to the dam (sluice) up $0+35 \mathrm{~m}$, downstream to the dam (sluice) down $0+82 \mathrm{~m} 76 \mathrm{~m}$ in total along the vertical direction, in which taking the top to $\nabla 1697 \mathrm{~m}$, and taking the bottom to $\nabla 1600 \mathrm{~m}$. The calculation model effectively reflects the geometric shapes of the sluice chamber structures, and the sluice chamber jointing is simulated with $20 \mathrm{~mm}$ soft element. As for the foundation, it basically adopts the actual positions of the original ground line, excavation line and bedrock surface line, and according to the geological conditions to perform generalization and partition to the foundation materials, and also take the influences of fault f201 into consideration.

Add three-fixed restraint to the foundation bottom, and add the normal bar chain restraint to each vertical side of the foundation. Take its coordinate system as : 0 point is set on the dam (sluice) axis $0+000.00 \mathrm{~m}$, dam (sluice) left and right $0+000.00 \mathrm{~m}$ and zero elevation $(\nabla 0.0 \mathrm{~m})$. The $\mathrm{X}$ axis points to the upstream along the direction of flow, $\mathrm{Y}$ axis points to the right side along the vertical direction of flow, $\mathrm{Z}$ axis points to the upper side along the vertical direction. The FEM network of sluice chamber system after the automatic split is as shown in Figure 1.

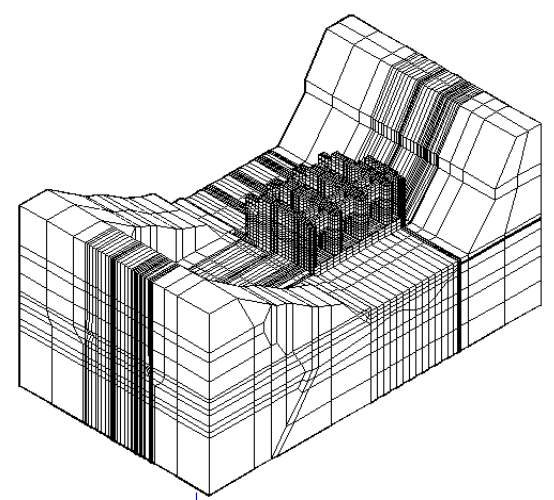

Figure 1. FEM network figure of sluice chamber system

\section{ACHIEVEMENT ARRANGEMENT AND ANALYSIS}

According to the above calculation models and parameters, perform calculations to the three typical working conditions such as completion period, highest storage period, and earthquake period, and solve the displacement and stress of the overall sluice chamber structure and foundation. Due to the limited space, we only perform arrangement and analysis to the major achievement. 
For the convenient description, number the three discharge sluice chambers as No. 1\#, 2\# and 3\# from left to right.

\section{A. Overall anti-slide, anti-floating stability and foundation reaction force of the sluice chamber structure}

Table 2 shows the overall anti-slide, anti-floating safety factor of each sluice chamber in the completion period, storage period and earthquake period as well as the largest foundation reaction force conditions.

TABLE II. ANTI-SLIDE, ANTI-FLOATING SAFETY FACTOR OF THE OVERALL SLUICE CHAMBER STRUCTURE

\begin{tabular}{|c|c|c|c|c|}
\hline $\begin{array}{l}\text { Sluice } \\
\text { chamber }\end{array}$ & $\begin{array}{l}\text { Working } \\
\text { condition }\end{array}$ & $\begin{array}{c}\text { Anti-slide } \\
\text { Safety } \\
\text { Factor }\end{array}$ & $\begin{array}{c}\text { Anti- } \\
\text { floating } \\
\text { safety } \\
\text { factor }\end{array}$ & $\begin{array}{l}\text { Foundation } \\
\text { reaction/MPa }\end{array}$ \\
\hline \multirow{3}{*}{$\begin{array}{l}\text { Spillway } \\
\text { sluice 1\# }\end{array}$} & $\begin{array}{c}\text { Completion } \\
\text { period }\end{array}$ & & & -1.11 \\
\hline & $\begin{array}{l}\text { Storage } \\
\text { period }\end{array}$ & 7.42 & 11.29 & -1.33 \\
\hline & $\begin{array}{l}\text { Earthquake } \\
\text { period }\end{array}$ & 5.41 & 11.04 & -1.37 \\
\hline \multirow{3}{*}{$\begin{array}{l}\text { Spillway } \\
\text { sluice 2\# }\end{array}$} & $\begin{array}{l}\text { Completion } \\
\text { period }\end{array}$ & & & -1.01 \\
\hline & $\begin{array}{c}\text { Storage } \\
\text { period }\end{array}$ & 7.03 & 11.89 & -1.01 \\
\hline & $\begin{array}{l}\text { Earthquake } \\
\text { period }\end{array}$ & 5.21 & 11.12 & -1.02 \\
\hline \multirow{3}{*}{$\begin{array}{l}\text { Spillway } \\
\text { sluice 3\# }\end{array}$} & $\begin{array}{l}\text { Completion } \\
\text { period }\end{array}$ & & & -0.90 \\
\hline & $\begin{array}{l}\text { Storage } \\
\text { period }\end{array}$ & 6.97 & 11.88 & -0.90 \\
\hline & $\begin{array}{l}\text { Earthquake } \\
\text { period }\end{array}$ & 5.20 & 11.16 & -1.00 \\
\hline \multirow{3}{*}{$\begin{array}{l}\text { Sand } \\
\text { sluice }\end{array}$} & $\begin{array}{l}\text { Completion } \\
\text { period }\end{array}$ & & & -2.16 \\
\hline & $\begin{array}{l}\text { Storage } \\
\text { period }\end{array}$ & 14.46 & 16.29 & -2.84 \\
\hline & $\begin{array}{l}\text { Earthquake } \\
\text { period }\end{array}$ & 11.87 & 15.04 & -3.03 \\
\hline
\end{tabular}

Fro $m$ this it can be seen that, the overall anti-slide, antifloating safety factor of each sluice chamber structure under each working condition satisfies the specification requirements.

\section{B. Displacement of the overall sluice chamber structure}

It can be discovered by performing arrangement to the displacement calculation result that, seeing from the overall deformation of the sluice chamber structure, as for the working conditions of completion period, along the upstream and downstream directions, it mainly shows as the deformation to the upstream, and the maximum value occurs at the top of pier of the discharge sluice, this is mainly because that the dead weight of the pier structure close to the upstream is larger than the dead weight close to the downstream. Along the left and right directions of the sluice chamber, it mainly shows as the deformation of the left side, which is mainly influenced by the side loading of reaction force on the left dam. The maximum value occurs at the top of the right pier of the downstream end of the sand sluice, which is mainly because that large backfilling pressure has been worked on the right sluice wall. Along the vertical direction it mainly shows as deformation to the downstream, which is mainly due to the function of foundation sedimentation, and generally speaking, the sedimentation on the left side is larger than the right side, the sedimentation of the discharge sluice is larger than the sand sluice, which is mainly because the foundation materials on the right side are better than the foundation materials on the left side, and in addition, the interactions of the side loading of foundation reaction force on the left side. As for the working conditions of the highest storage level, due to the functions of the horizontal water pressure, the deformation along the upstream and downstream directions of the sluice chamber change from pointing to the upstream in the completion period into pointing to the downstream. The deformation along the left and right direction of the sluice chamber, compared with that in the completion period, the direction basically remains unchanged, but due to the functions of the water pressure, the deformation value of each point has been changed somewhat. The deformation along the vertical direction, compared to that in the completion period, remains unchanged in the direction, but the downward sedimentation value increases somewhat, which is due to the function of the water weight, and in addition, there is curtain for seepage control in the upstream, and no water in the downstream, the total water weight is larger than the function of the uplift pressure. After taking the earthquake function into consideration, and compared with the storage period, the basic deformation status of the sluice chamber structure remains unchanged, but the value increases somewhat, and the increased ratio is relatively small.

Seeing from the displacement of each jointing among the sluice chambers, the relative displacements between the jointing are relatively small, and the displacements on the left and right direction of the sluice chamber have no embedding phenomenon. The relative displacements on the jointing can provide evidences to the caulk materials and waterstop design.

In Table 3 it provides the maximu $\mathrm{m}$ displacements and their locations of the overall sluice chamber structure under three calculation working conditions. In which, $\mathrm{U}_{\mathrm{x}}$ is the displacement on $\mathrm{X}$ direction, that is the displacement on the up and down directions of the dam (sluice), $U_{y}$ is the displacement on $\mathrm{Y}$ direction, that is the displacement on the left and right directions of the dam (sluice), $U_{z}$ is the displacement on $\mathrm{Z}$ direction, that is the displacement on the vertical direction.

TABLE III. MAXIMUM DISPLACEMENTS AND THEIR LOCATIONS OF THE OVERALL SLUICE CHAMBER STRUCTURE

\begin{tabular}{|c|c|c|c|c|c|}
\hline $\begin{array}{c}\text { Wor } \\
\text { king } \\
\text { cond } \\
\text { ition } \\
\mathrm{s} \\
\end{array}$ & $\begin{array}{c}\text { Weig } \\
\text { ht }\end{array}$ & $\begin{array}{l}\text { Displaceme } \\
\text { nt /mm }\end{array}$ & $\begin{array}{l}\text { Upper and } \\
\text { lower pile No. } \\
\text { Of sluice /m }\end{array}$ & $\begin{array}{l}\text { Left and right } \\
\text { pile No. Of } \\
\text { sluice /m }\end{array}$ & $\begin{array}{c}\text { Elevatio } \\
\mathrm{n} / \mathrm{m}\end{array}$ \\
\hline $\begin{array}{l}\text { Com } \\
\text { pleti }\end{array}$ & $\mathrm{U}_{\mathrm{x}}$ & 4.46 & $\begin{array}{c}\text { Lower } \\
0+29.41\end{array}$ & right $0+3.00$ & 1676.0 \\
\hline $\begin{array}{l}\text { poll } \\
\text { on } \\
\text { perio }\end{array}$ & $\mathrm{U}_{\mathrm{y}}$ & -22.61 & $\begin{array}{c}\text { Lower } \\
0+42.00\end{array}$ & right $0+56.00$ & 1668.0 \\
\hline $\begin{array}{c}\text { perio } \\
\text { d }\end{array}$ & $\mathrm{U}_{\mathrm{z}}$ & -34.05 & $\begin{array}{c}\text { Lower } \\
0+0.00\end{array}$ & right $0+0.00$ & 1674.9 \\
\hline Stor & $\mathrm{U}_{\mathrm{x}}$ & -5.18 & $\begin{array}{c}\text { Lower } \\
0+42.00\end{array}$ & right $0+0.00$ & 1647.0 \\
\hline $\begin{array}{l}\text { age } \\
\text { perio }\end{array}$ & $\mathrm{U}_{\mathrm{y}}$ & -21.69 & $\begin{array}{c}\text { Lower } \\
0+42.00\end{array}$ & right $0+56.00$ & 1668.0 \\
\hline $\mathrm{d}$ & $\mathrm{U}_{\mathrm{z}}$ & -36.71 & $\begin{array}{c}\text { Lower } \\
0+0.00\end{array}$ & right $0+0.00$ & 1674.9 \\
\hline $\begin{array}{l}\text { Eart } \\
\text { hqua }\end{array}$ & $\mathrm{U}_{\mathrm{x}}$ & -6.46 & $\begin{array}{c}\text { Lower } \\
0+42.00\end{array}$ & right $0+0.00$ & 1647.0 \\
\hline $\begin{array}{l}\text { ke } \\
\text { perio }\end{array}$ & $\mathrm{U}_{\mathrm{y}}$ & -22.34 & $\begin{array}{c}\text { Lower } \\
0+42.00\end{array}$ & right $0+53.50$ & 1668.0 \\
\hline $\mathrm{d}$ & $\mathrm{U}_{\mathrm{z}}$ & -37.27 & $\begin{array}{c}\text { Lower } \\
0+0.00\end{array}$ & right $0+0.00$ & 1674.9 \\
\hline
\end{tabular}


From this figure, it can be seen that under various calculation working conditions, the maximum horizontal displacements on the upstream and downstream directions of the sluice chamber occur in the earthquake period, and the maximum value is $-6.46 \mathrm{~mm}$, with the direction pointing to the downstream, and the location is at the key wall bottom of the bottom plate on the downstreamend of the discharge sluice; the maximum horizontal displacement on the left and right direction of the sluice chamber occurs in the completion period, and the maximum value is $-22.61 \mathrm{~mm}$, with the direction pointing to the left side, and the location is at the top of the pier on the downstream end of the sand sluice; the maximum vertical displacement occurs in the earthquake period, and the maximum value is $-37.27 \mathrm{~mm}$, with the direction pointing to the downward, and the location is at the top of the pier on the upstream end of the discharge sluice.

\section{Stress of the overall sluice chamber structure}

Table 4 provides the maximum positive stress, main stress and their locations of the overall sluice chamber structure. It can be seen from this figure that, under the three categories of loading working conditions of completion period, storage period and earthquake period, the maximum positive stress $\sigma_{x}$ occurs at the corbel of the discharge sluice in the earthquake period, and the maximu $\mathrm{m}$ value is $4.57 \mathrm{MPa}$ the maximu $\mathrm{m}$ positive stress $\sigma_{y}$ occurs at the corbel of the sand sluice in the earthquake period, and the maximu $\mathrm{m}$ value is $4.81 \mathrm{MPa}$ the maximum positive stress $\sigma_{z}$ occurs at the corbel of the sand sluice in the earthquake period, and the maximum value is $2.63 \mathrm{MPa}$, the maximum main stress $\sigma_{1}$ occurs at the corbel of the sand sluice in the earthquake period, and the maximum value is $6.35 \mathrm{MPa}$ the minimum stress $\sigma_{3}$ occurs at the corbel of the sand sluice in the earthquake period, the maximum value is $-16.26 \mathrm{MPa}$ 。
TABLE IV.

THE MAXIMUM POSITIVE STRESS, MAIN STRESS AND THEIR LOCATIONS OF THE OVERALL SLUICE CHAMBER

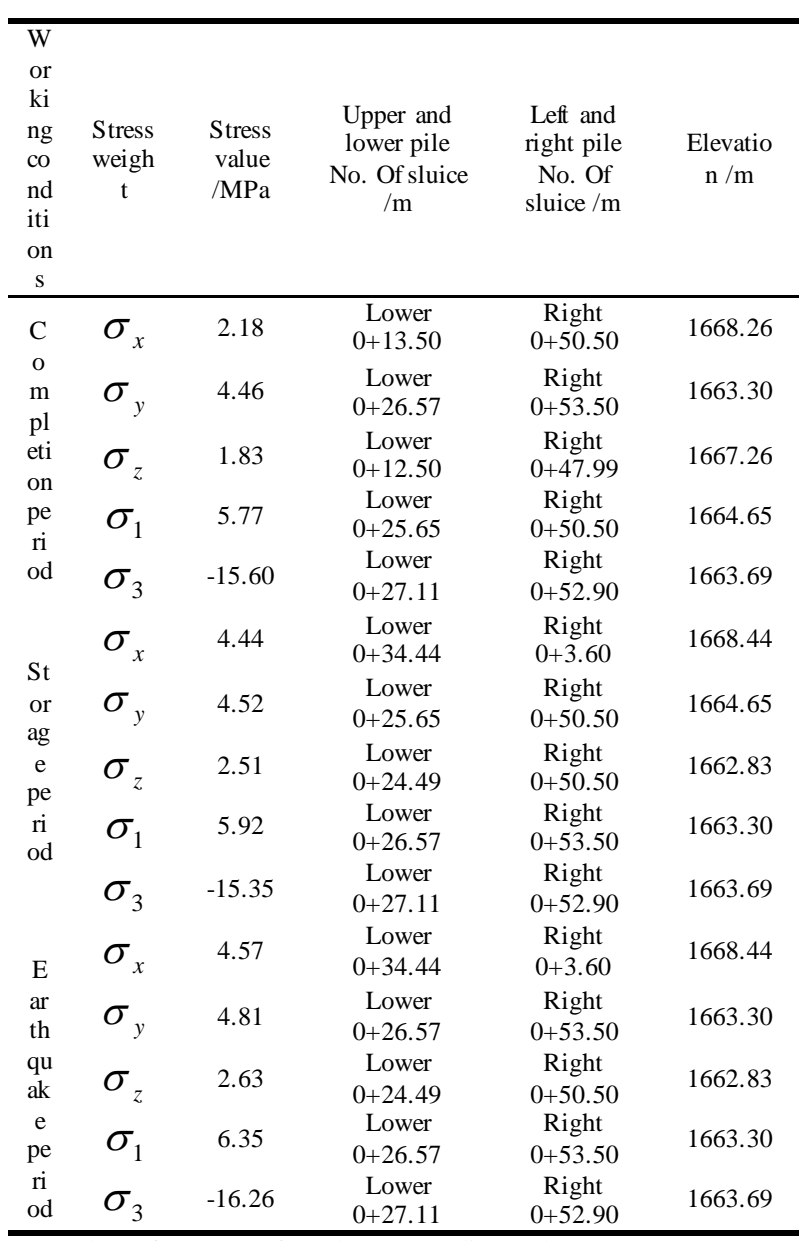

Therefore, as for the complicated stress status at the corbel and the stress concentration phenomenon, we should pay great attentions.

\section{CONCLUSIONS}

In this article, it adopts the space combination FEM method to calculate the sluice chamber structure and the overall displacement and stress, use the superposition principle to calculate the internal force of the section, and calculate the overall anti-slide safety and anti-floating safety factors according to the limit equilibrium for rigid body analysis, and the calculation model effectively takes the interactions between the sluice chamber structure and the foundation into consideration, and also takes the influences of the concrete dams on both side of the sluice chamber structure. It performs calculation and analysis to the three typical working conditions, and the obtained calculation result complies with the general rules, which means that the obtained calculation model and method are reasonable and feasible.

Through the overall anti-slide and anti-floating safety factors of the sluice chamber structure, the normal stress of the foundation as well as the displacement, stress and internal force calculation of the overall sluice chamber structure, and with the comprehensive analys is it shows that seeing from the rigidity, strengthen and stability of the he first hub dam sluice dam sluice chamber structure overall design project of the hydroelectric power is feasible 
and reasonable. And its results are of some reference functions for the similar projects.

\section{REFERENCES}

[1] Design Specification for Sluice[M]. Beijing: China Water\& Power Press, 2001.

[2] D.CZienkiewicz. Definite Element Method [M], Beijing: Science Press, 1985.

[3] Peng Xuan-mao. Simulation and calculation of the old practical weir sluice, Journal of Hohai University, 2004, 32(3):279-281.

[4] Hu Zhao-qiu. Modern Calculation Method of Sluice Structure Design and Its Application Research[D].Nanjing: Hohai University, 2003(12)

[5] Tian Qian-li. Simple Solution of Plane Problem Elastic Foundation[J]. Science Bulletin, 1974 5th season(Mimeographed Version of
Port\& Channel Engineering Department of Transportation Bureau, Anhui Province).

[6] Zhang Zi-ming. Calculating the Displacement and Stress of Multilayered Foundation with the Initial Function Algorithm[J]. Chinese Journal of Geotechnical Engineering, 1986.

[7] Zhao Guang-heng. Foundation Model and basic beam-slab analysis[J].Hohai University Science \& Technology Information, 1990.

[8] Chen Guo-rong. Theory of Elasticity[M]. Nanjing: Hohai University Press, 2000.

[9] Long Yu-qiu. Calculation of Elastic Foundation Beam[M].. Beijing: People's Education Press, 1981.

[10] Zhang Yong-sheng, Liang Li-fu. Finite Element Analysis of the overall stability and Elasticoplasticity of Sluice Foundation[J]. Journal of Changsha University, 2013.12. 